\title{
SWEARING WORDS ON YOUTUBE COMMENT COLUMN IN CNN POLITICAL NEWS
}

\author{
Febby Halimah Lubis, Ridwan Hanafiah, Dian Marisha Putri \\ University of Sumatera Utara (USU), Medan, Indonesia \\ E-mail: febbyhalimahlubis@gmail.com
}

Received: 2020-08-10

Accepted: 2020-12-04

\begin{abstract}
This study aimed to identify the types of swearing words and the reasons of swearing words that are used on YouTube comment column. This study conducted a descriptive qualitative research. The source of the data was taken from comment column of video uploaded by CNN about political news on YouTube. In analyzing the data, the researchers employed the theory proposed by Lakoff (1975) in order to identify the types of swearing word and the theory of Andersson (in Karjalainen, 2002:23) in order to describe the reasons of swearing word. The result of this study revealed that there were two types of swearing word, which were strong and weak swearing word and three reasons of swearing words, which were psychological, social and linguistic motive. The most dominant type was strong swearing word and the most dominant reasons of using swearing word was psychological motive. The word fuck as the powerful taboo word was the most dominant word contained in the expressions of swearing word.
\end{abstract}

Keywords: Sociolinguistics, Swearing Words, Comments

\section{Introduction}

Swearing has evolved thousand years ago to represent human expression. Nevertheless, before the nineteenth century, swearing is not popular and strictly forbidden. Allan and Burridge (2006) state that swearing words are those considered offensive, shocking, or indecent when used in certain context, there are strict conditions on its use and penalties for violating these conditions. Recently, the use of swearing is different from the past. Swearing becomes more popular as can be seen in our daily life as well as in many Medias, both in spoken and written conversation, more specifically in comment column.

The use of swearing words often takes place in social media network sites. Along with the advancement of technology, social media has become a common platform for communication. People are free to write what they want to say through comment column. No one controls and limits the freedom of expression in using it. For instance, YouTube as one the popular social networking sites in which thousands of videos are being uploaded everyday by its user.

YouTube allows its user to communicate through video comment and ratings (Halpern \& Gibbs, 2013). YouTube users are free to comment and discuss through the comment column on various video posted. Various YouTube channels deal with particular issues, it can be about science, education, entertaiment, and the popular one is political issues. These videos 
Swearing Words on Youtube Comment Column in CNN Political News, Febby Halimah Lubis, Ridwan Hanafiah, Dian Marisha Putri

are made available to the public to debate and discussed upon. Additionally, YouTube is a community in which rule for online behavior is not strictly forbidden.

Regarding to the political issues, CNN (cable news network) is one of the popular channels in YouTube. CNN is an American News channel that mainly broadcast political news. CNN has more than eight million subscribers and uploaded one hundred forty seven thousands of videos on its own YouTube channel. People around the world easily reach the accessibility of those videos to debate and discussed through the comment column. Moreover, YouTube is a community in which rule for the language usage is no control and the viewer who wants to comment do not required to disclose any personal information. Thus, the researcher found that many comments contain swearing words is there to strengthen strong emotion such as dislike, dissatisfaction, anger, and surprise.

\section{Literature Review}

Related to swearing phenomenon, many researchers have conducted for several times. First, a sociolinguistics research entitled An Analysis of Taboo Word and Swear Word in Dustin Lee Abraham's How High Movie, was done by Aditia (2011). The purposes of this study is to classify the types of taboo words and the factor which cause the characters use the taboo words and swear word in this movie. The result of this study showed that there are four types of taboo word that found in How High movie. Moreover, there are two types of swear word that found in How High movie such as strong swear word and weak swear word. This research contributes to the ongoing research to analyze types of swearing in terms of the theory that based on Swan (1995).

From the previous researches focused on language usage, the researcher mainly found the oral media such as movie, vlog and song as the object of the study. Afterwards, there have been limited studies concerned on how language used on written media such as YouTube comment column. Thus, the research intends to analyses the phenomenon of language usage, more specifically swearing word on YouTube comment column. The study only focuses on analyzing the types and reasons of swearing word found in comment column of videos uploaded by CNN on YouTube.

\section{Research Method}

This study conducts a descriptive qualitative research. Bungin (2007) states that in descriptive qualitative research, data collecting method and technique of data analysis are tied inseparably, because the data analysis method and technique have actually been started since the data collection has been conducted. This kind of research describes and explains a phenomenon as it is. The source of data in this study was taken from comment column of video uploaded by CNN about political news on YouTube. The researcher only focuses on comment that contains swearing words. The data will be analyzed, classified, and described in order to answer the problem of the study. Moreover, the researcher takes 17 data to be analyzed from three most commented videos about Political News from CNN on YouTube from the website https://www.youtube.com/user/CNN. This research is collected by using documentary method, in which only the data that support the research question are taken.

\section{Results and Discussion}

The analysis puts the focus on the types of swearing words and the reasons of swearing words used on YouTube comment column in CNN Political News. There are two types of 
swearing words that are used by participant in commenting the CNN political news on YouTube comment column they are strong and weak swearing word. Three reasons of swearing words that are used by participant; they are psychological motive, social motive, and linguistic motive.

Table 1 Types of Swearing Word

\begin{tabular}{lll}
\hline No & Types & Total \\
\hline 1 & Strong & 13 \\
2 & Weak & 4 \\
& Total & 17 \\
\hline
\end{tabular}

Based on the analysis of 17 data used in this study, it is found that types of swearing word in this study is dominated by strong swearing words, which is 13 data from data analysis. On the other hand, it is only found 4 for the types of weak swearing words.

Table 2 Reasons of Swearing Word

\begin{tabular}{lll}
\hline No & Reasons & Total \\
\hline 1 & Psychology & 8 \\
2 & Social & 3 \\
3 & Linguistic & 6 \\
& Total & 17 \\
\hline
\end{tabular}

Reason of swearing word in this study is dominated by Psychological motive, which is 8 data and 6 data for linguistic motive from data analysis. Social motive is the lowest reasons used by participant, which is 3 data from 17 data analysis.

\subsection{Analysis of Types of Swearing Word}

Strong swearing word can be identified by seeing the taboo word that has rude character and it does not maintain its literal meaning. Moreover, it should be interpreted according to their emotive sense. Meanwhile, weak swearing word pertains to the taboo word that has mild character and it does not maintain its literal meaning. Moreover, it should be interpreted according to their emotive sense as can be seen from the following data below.

a. Adam Shortnacy: as long as Trump is president I don't give a fuck, just like you didn't when Buma was president

The expression of "I don't give a fuck" is regarded as strong swearing word and characterized as a way to express emotion in order to exclaim an unconcern toward something. The word fuck in the expression pertains to taboo word and refers to sexual activity. The literal meaning of fuck is having sex with someone and generally used in informal situation. Fuck is the most taboo and powerful rude in English. In this expression, the word fuck does not maintain its literal meaning and it has rude character in the sense of unconcern toward something.

b. Audihostem187: so at the end of this very long drawn-out process no witness and no trial? What the hell is going on here?.

This data is regarded as weak swearing word and presented by the expression "what the hell is going on here" and it is interpreted as a surprised question. The word hell in this 
Swearing Words on Youtube Comment Column in CNN Political News, Febby Halimah Lubis, Ridwan Hanafiah, Dian Marisha Putri

expression pertains to taboo word and one of religious types of mild taboo word. The word hell means the place where some people are believed to go after death to be punished forever for the bad things they have done during their live, the word hell also refers to unkind-bed tempered. But in this expression, the word hell does not mean to the place but used as expression.

\subsection{Analysis of Reasons of Swearing Word}

Psychological motive emphasize that swearing words is used to release stress and related to personal emotions. Meanwhile, social motive can be used to show social intimacy and distance to other people. Linguistic motive is uttered to give emphasize on what people try to communicate and something being discussed as can be seen from the following data below.
a. $E P$
: holy shit you are stupid

The expression above written by $\mathrm{E} P$ is categorized as an expression contained swearing words which is influenced by psychological motive since it is employed to show the personal participant's emotion in order to express annoyance.

b. Dude Bro : Donald Trump doesn't trust China! China is Asshole

The expression written by Dude Bro "China is Asshole" is categorized an expression contained swearing words which is influenced by social motive. He showed his hatred toward China and saying that china is Asshole. The word Asshole is strong taboo word used to show hatred toward community that can cause insult.
c. Xun Gu
: give me fucking link. Who is DR. Z?

The expression "give me fucking link" written by Xun Gu is categorized as an expression contained swearing word which is influenced by linguistic motive. The word "fucking" as an adjective word in this expression is used to give emphasize to what Xun Gu asking for.

\section{Conclusion}

The researcher found that there are two types of swearing words; they are strong and weak swearing word. The most dominant type of swearing words that is used by participant in commenting the CNN political news on YouTube comment column is strong swearing word. Moreover, there are three reasons of swearing words; they are psychological motive, social motive, and linguistic motive. The most dominant reason of swearing word is psychological motive. The word fuck as the powerful taboo word is the most dominant contained in the expressions of swearing word.

Strong swearing word and psychological motive are the most dominant types and reasons of swearing in this study. Those are very offensive and impolite to be used in formal situation. CNN as the object of the data is legal YouTube channel, which mainly posts about political news. On the other hand, YouTube is a community in which rule for the language usage is no control and the participants who want to comment do not required to disclose any personal information. Moreover, Political issue is one of the popular issue in which people are interested to debate and sometimes causing pro and contra. Thus, it is no doubtful that the participant highly used strong swearing words in order to express and strengthen their personal emotion. 


\section{References}

Aditia, Hendri. (2011). An Analysis of Taboo Word and Swear Word in Dustin Leen Abraham's How High Movie. Thesis. UIN Syarif Hidayatullah Jakarta.

Allan, Keith \& Kate Burridge. (2006). Forbidden Words: Taboo and the Censoring of Language. New York: Cambridge University Press.

Bungin, Burhan. (2007). Penelitian Kualitatif: Komunikasi, Ekonomi, Kebijakan Publik, dan IImu Sosial Lainya. Jakarta: Kencana Prenada Media Group.

Halpern, D., \& Gibbs, J. (2013). Social media as a catalyst for online deliberation? Exploring the affordances of Facebook and YouTube for political expression. Computers in Human Behavior, 29(3), 1159-1168.

Hanafiah, Ridwan \& Yusuf, Muhammad. (2016). Lexical Density and Grammatical Intricacy in Linguistic Thesis Abstract: A Qualitative Content Analysis. University of Sumatera Utara.

Karjalainen, M. (2002). Where have all the swearwords gone: An analysis of the loss of swearwords in two Swedish translations of J. D. Salingers Catcher in the Rye.

Lakoff, Robin. (1975). Language and Woman's Place. Toronto: Fitzhenry and Ehitside Limites. Swan, Michael. (1995). Practical English Usage. $2^{\text {nd }}$ ed. New York: Oxford Up. 